DOE NASA 2674.79/7

NASA TM-79249

\title{
NASA LEWIS CLOSED-CYCLE MAGNETOHYDRODYNAMICS PLANT ANALYSIS
}

Paul F. Penko

National Aeronautics and Space Administration

Lewis Research Center

Work performed for

U.S. DEPARTMENT OF ENERGY

Energy Technology

Magnetohydrodynamics Division

Prepared for

Cbsed-Cycie Magnetohydrodynamics

Specialists Meeting

Bozeman. Montana. June 21, 1979

(1251--7-79249) HASA-LEHIS CLOSED-CTCLE

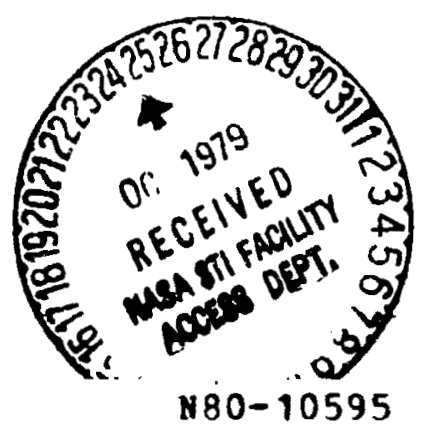

EIEDEOEIDRODIRATICS PLAKT ANALTSIS (NASA)

33 E $102 / \mathrm{P} \quad 101$

CSCL 10A 
DOE/NASA/2674-7977

NASA TM-79249

\section{NASA LEWIS CLOSED-CYCLE \\ MAGNETOHYDRODYNAMICS \\ PLANT ANALYSIS}

Paul F. Penko

National Aeronautics and Space Administration

Lewis Research Center

Cleveland, Ohio 44135

Prepared for

U.S. DEPARTMENT OF ENERGY

Energy Technology

Magnetohydrodynamics Division

Washington, D.C. 20545

Under Interagency Agreement EF-77-A-01-2674

Closed-Cycle Magnetohydrodynamics

Specialists Meeting

Bozeman, Montana, June 21, 1979 


\title{
NASA LEWIS CLOSED-CYCLE MAGNETOHYDRODYNAMICS PLANT AHALYSIS
}

\author{
by Paul F. Penko \\ NASA Lewi Reserch Center \\ Cleveland, Ohio
}

The NASA Lewis Research Center is presently wanaging two otudy contracts to analyze coal-fired closed cycle MAD power plants. The studies will serve to quantify the effects of various system parametera on plant performance, capical cost, and cost of electricity. In support of the contracted studies, the Lewis Research Center has conducted plant analysis of a preliminary nature to survey the basic effects of various system parameters on plant performance. This pesentation briefly reviews the ascuptions and results of the analyses to date.

Each of the wain subsystems, i.e., the inert gas (argon) MAD loop, the steam bottconing cycle and the combustion system, was considered in detail. The combined cycle, consisting of the inert gas MHD and ateam cycles was first analyzed and then interfaced with three types of combustion systems.

To provide an overview of combined cycle thermal analysis, several cycle parameters were varied and several configurations examined. Variations were made in the steam plant such as level of regenerative feedwater heating and condenser back pressure; and in the inert 8 as MHD loop such as compressor intercooling, recuperation, MHD generator efficiency and inlet temperature, and component heat and pressure losses. Also, the effect of cunstraining the design point parameters and the cycle interfacing such that the steam plant power output matched the argon compressor power requirement was considered. The generation of additional steam in the combustion loop for use in the steam plant was also examined.

Generally, the trends are that steam cycle regenerative feedwater heating, compressor intercooling and combustion loop steam generation tend to degrade performance. The benefit of MHD loop recuperation is marginal, with cycle efficiency highly dependent on recuperator pressure loss. Lowering steam plant back pressure enhances overall cycle performance, as does raising MHD generator efficiency and inlet temperature. A design point without the constraint of balancing steam cycle and compressor power to allow for maximum MHD channel enthalpy extraction can improve cycle performance.

A very important aspect in the determination of plant performance and capital cost is the type of combustion system used to supply heat to the combined cycle. To focus on the effect that various combustion systems have on plant performance, a combined MHD/steam cycle was selected as a reference power producing cycle and coupled to each of three combustion systems. The design point For the reference cycle was chosen as the point at which the steam plant output power exactly matched the argon compressor power requirement. The MHD 
channel wa perametrically assigned on isentropic efficiency of 780 and en inlet cemperature of $1977 \times\left(3100^{\circ} \mathrm{F}\right)$.

The reference combined cycle is shown schematically in figure 1 and is aigilar to GE ECAS systea (refs. I to 3). The condition of a blance between ster plant and compessor power dictaces a channel preseure ratio of 4.8 , a corresponding enthalpy extraction of 36\%, and a diffuser exit tesperature of $1257 \mathrm{~K}\left(1804^{\circ} \mathrm{F}\right)$. The or.ean bottoning plant extracts wate heat from the ergon eriting the char: \& diffuser in a series of heat recovery comonents. Continuing th:ough $\mathrm{tl}$ : ycle, the ergon is further cooled with coolin tower water prior to being compressed to a pressure ratio of 5.5 to overcome ey ated pressure losses. Following compresaion, the argon is heated in an array of refractory brick regenerative heaters that are alternately valved betwen combustion gas and argon. For the sake of brevity, seed recovery and reprocessing, agon purifying, and regenerative heater evacuation equipmant necesery for a functioning plant are not hown in figure 1.

The bottoming plant is a $\left.24.1 \mathrm{MN} / \mathrm{m}^{2} / \mathrm{f} .1\right) \mathrm{K} / 841 \mathrm{~K}\left(3500 \mathrm{psia} / 1000^{\circ} \mathrm{F} /\right.$ $1000^{\circ} \mathrm{F}$ ) supercritical, reheat seam cycle iith an argon loop interface consisting of a reheater, superheater, deaerator, and economizer. The minimum temperature difference between argon and atean in these heat exchangers was liaited to $28 \mathrm{~K}\left(50^{\circ} \mathrm{F}\right)$. Condenser back pressure was set at $8.5 \mathrm{kN} / \mathrm{m}^{2}(2.5 \mathrm{in}$. $\mathrm{Hs}$ ) for a feedwater temperature of $316 \mathrm{~K}\left(110^{\circ} \mathrm{F}\right)$. To maximize heat extraction from the topping cycle, no regenerative feedwater heating was used. For the given steam plant conditions, efficiency based on shaft pover is 387 as derived from the MASA steam cycle performance code.

The thermal efficiency of the combined cycle for the given conditions is 51.77 , defined as gross electrical power divided by heat input to the topping cycle. An energy flow diagram for the cycle is illustrated in figure 2.

Three different combustion systems to supply heat to the MhD/steam cycle were investigated. The first used a direct coal-fired combustor, the second used fluidized bed gasifier with in-situ desulfurization, and the third used a fluidized bed gasifier with external product 8 as cleanup. The heat and mass balances for the gasifiers were obtained from the ECAS study (ref. 5). All three combustion systems were pressurized, representing advanced systems, and used recuperation to most advantageously recover sensible heat from product andor flue gas in lieu of generating steam. Also, flue gas recirculation was incorporated in each case to limit combustor exit cemperature to $2116 \mathrm{~K}$ $\left(3350^{\circ} \mathrm{F}\right)$ and, hence, $\mathrm{NO}_{x}$ formation.

The direct coal-fired combustion system is shown in figure 3. The system is pressurized by an air compressor driven from a flue gas turbine. Compressed air is delivered to the combustor together with dried coal (Illinois $* 6$ for all cases) and recirculated flue gas. The combustion products heat the regenerative ceramic heaters, with the residual thermal energy exiting the heaters used for air preheat, turbine drive, and coal drying. An electrostatic precipitator (ESP) removes particulates carried over from the combustor upstream of the turbine and a dry spray scrubber/ESP removes $\mathrm{SO}_{2}$ and particulates downstream of the turbine prior to coal drying and stack exhaust. 


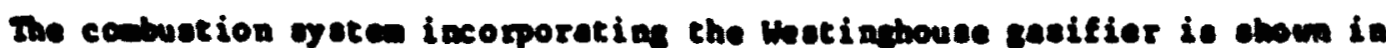
figure 4. The gaeifier conalote of two main otages: an upper dewolatilieszl deculfurizer bed fluidized by geses fron a lower geelficetion bod. Dolenite corbent is injected in the upper bed to renow bydrogen oulfide lorned in both bede frow sulfur in the coel. Two eteges of cyclonse and a gramular bed filter monow particulates froe the $1136 \mathrm{~K}(15850 \mathrm{~F})$ fuel ges. Process atem is gew erated and weter beated by cooling the product gas prior to combuetion. Gasifier procean air and combuetor air are probeted by hot flue gee leavin the refrectory ergon betera. The syatem is preseurised by an air compreseor driven by Ilve sas surbin.

The conbuetion ayate uein the IGT gesifier is shown in figure 5. The gerif ier is comprised of a min veseel and two at ages of cycles for particulate remova:. The fuel see exite the unit at $1311 \mathrm{~K}$ (19000 F) conteinin oulfur in the form of hydrozen sulfide. The fuel ge: i cooled to 877 R ( $1120^{\circ}$ f) by tranaferring heat to the procese steas and $\mathrm{r}$ and to the combustor air. An array of iron oxide bede renowe sulfur from the gea by coavert in hydrogen oulfide to iron sulfide. Periodically, the iron oxide beds are regenerated with air to oxidise the iron sulfide deposits. The oulfur dionide in the regeneration air is then reduced to elemental oulfur in an Allied Caenicel pleat wich requires 4.62 of the clean fuel sas. The syatem is presourized by a compreseor-turbine set ainiler to the preceeding case.

Energy diagrans comperine the combustion oysteme are shown in figure 6 . The oy ateas a re compered on a combon base of 100 heat units input to the combined Mab/etes cycle. The direct coal-fired case has the highest combuetion loop efficiency followed by the Westinghouse and IGT gasifier systens. The direct cosl-fired combustor is potentially the highest efficiency conbustion syatem but does present the formidable technical problems of operating regenerative heat exchangers with ash laden gas and operating turbine on gas containing sulfur, particulates and alkalies. Gasifiers result in a lower combustion syates efficieticy but provide the potential for lesser operetional problems of downetream couponent \&.

Overall plant efficiencies using the three combustion systems coupled to the combined mo/steam cycle are shown in figure 7. The direct coal-fired combuator plant has an overall efficiency (excluding auxiliaries) of $44.5 \%$, the Westinghouse gasifier plant 43\%, and the IGT gasifier plant 41\%. For purposes of comparison, two GE cases, one utilizing a direct coal-fired combustor, ECAS case $102 A$ (ref. 2), and the other a pressurized moving bed gasifier with in-bed desulfurization (ref. 3) are 1 so shown on the figure. The differences in plant efficiency between the corresponding GE and NASA cases a re reconcilable and lie in assumed MHD loop pressure and heat losses, steam plant conditions, end combustion system losses. The basic trends are aimilar, with the GE cases also -howing that a pressurized coal combustor plant has the highest potential efficiency.

As plant performance and costs are dependent on many varied and interrlated factors, wide range of parameters, components and configurations will be considered in the contracted studies. Such variations as type of coal, gasifiers, cleenup methods, pressure level and losses, MHD channel efficiency, component 


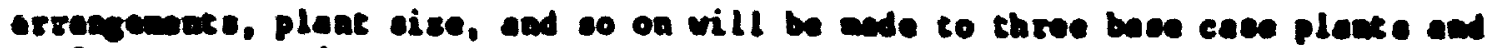
performene, capical coet and cost of electricity colculated for each particuler

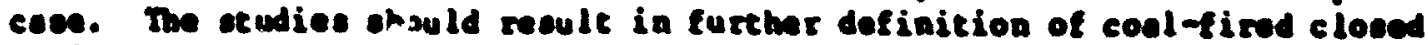
cyele hap plante beyond the lewel of EChs.

\section{mingers}

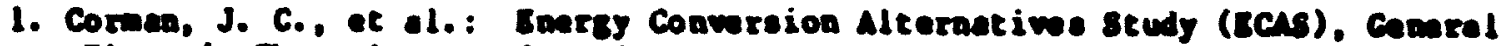

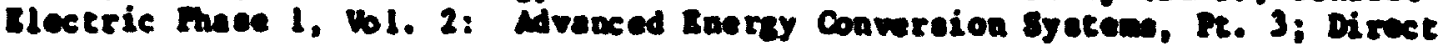
Bnerzy Conweraion Cycles. (820-76-011-Vol-2-Pt-3, Conrel Electric Co,: una Contract MAs3-19406.) MSA CA-134948-bol-2-Pe-3, 1976.

2. Zauderer, B.: Syotem studies of Coal Fired - Cloeed Cycle rab for Conerol seacion fower plente. Intereociety Energy Convreien Eninering Coferece, 11th, Vol. 2. Anerican Institute of Chemicel Entinere, 1976, Pp. 1033-1039.

3. Zauderer, B.; et al.: Coll Fired Hor-Bquilibriue, Closed Crcle rap/steca Caneration. Ast Paper 77-WNENER-8, Nov. 1977.

4. Comprative Evaluation of Phase 1 Deulte from the Energy Conversion Alternative study (BCAS). MASA Ay $x-71855,1976$.

5. Evaluation of Thase 2 conceptual Designs and Implemntation Asececment newiiing from the Energy Conversion Alternatives Study (ECAS). MAA MI X-73sts, 1977. 


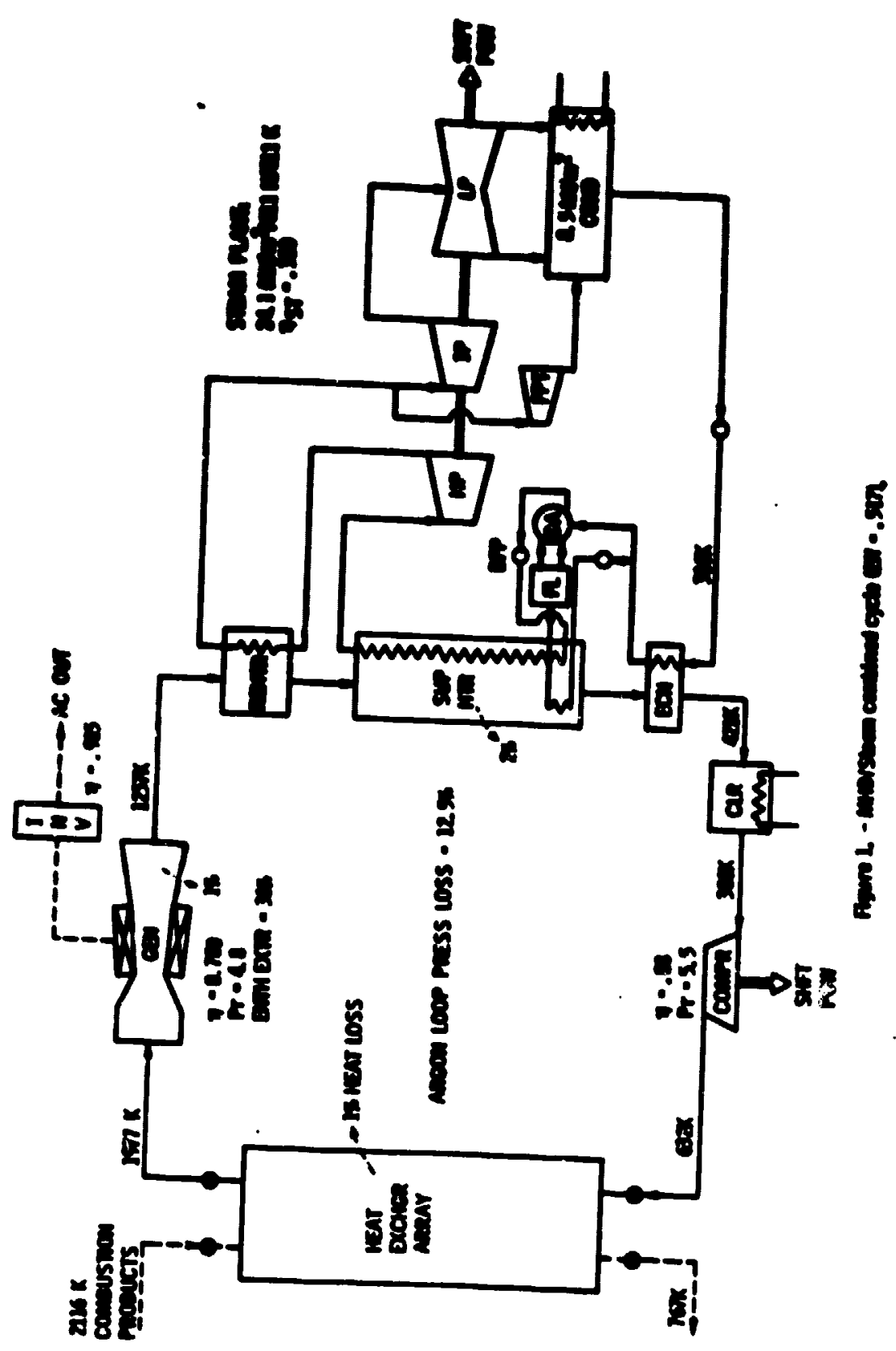




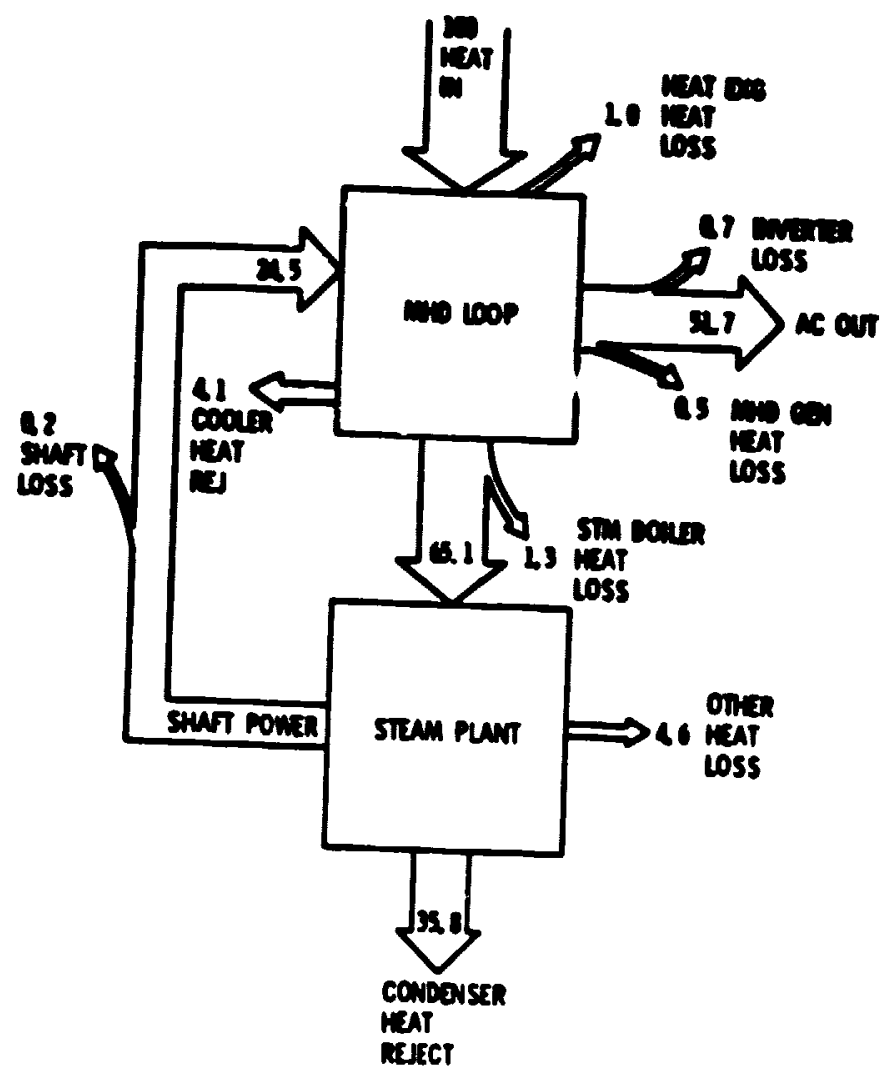

Fhure 2 - mho/stom energy diaram 


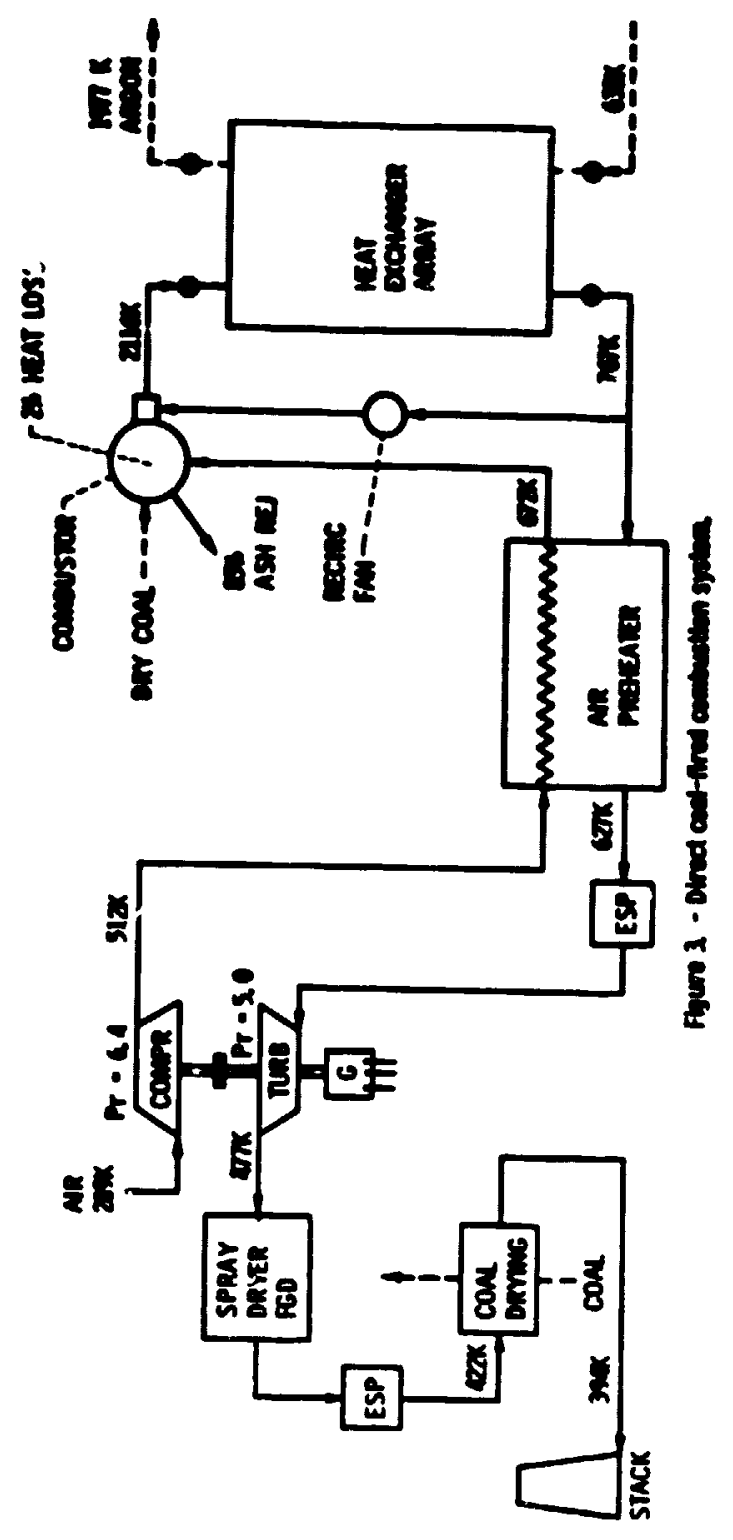




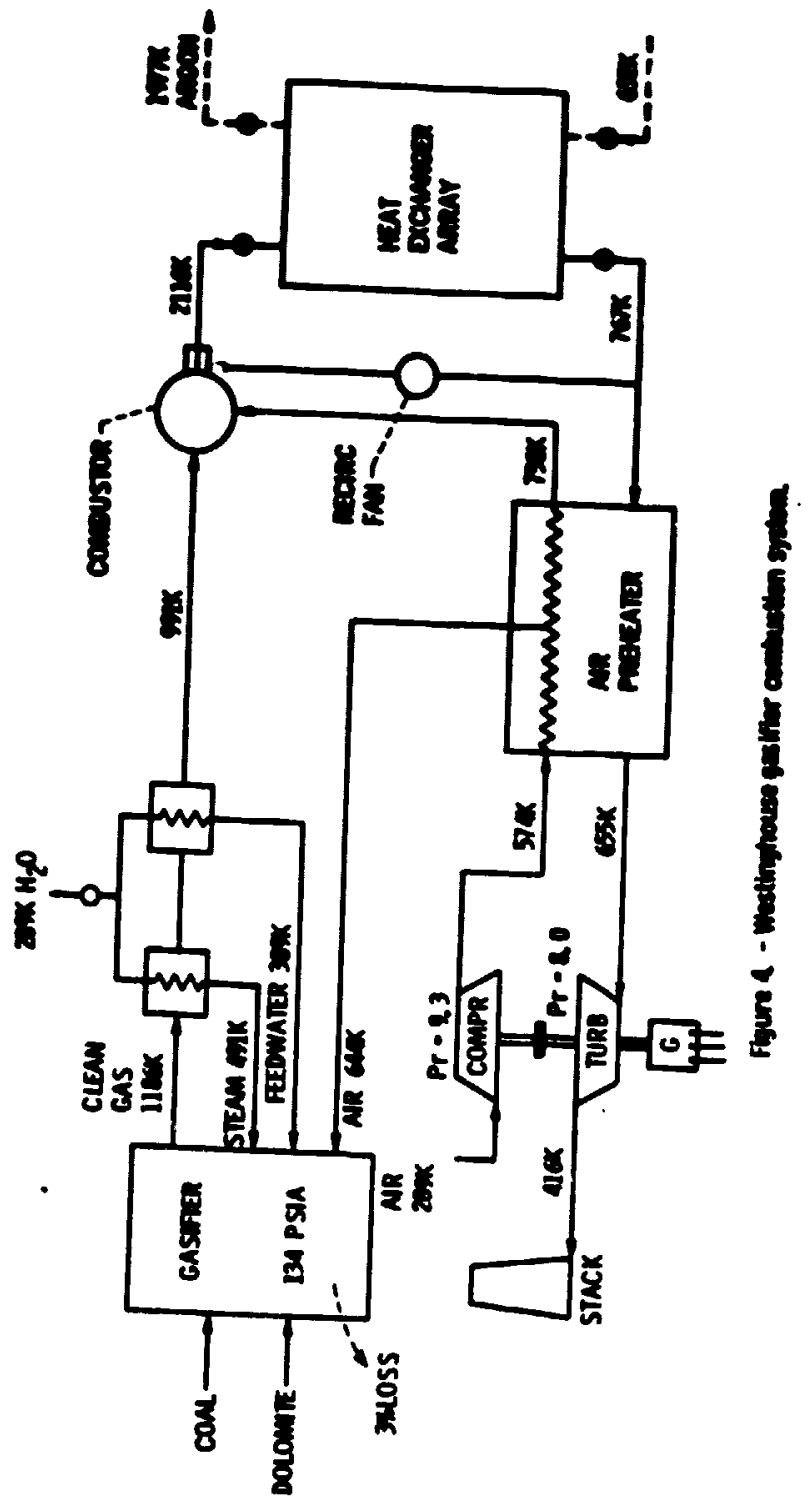




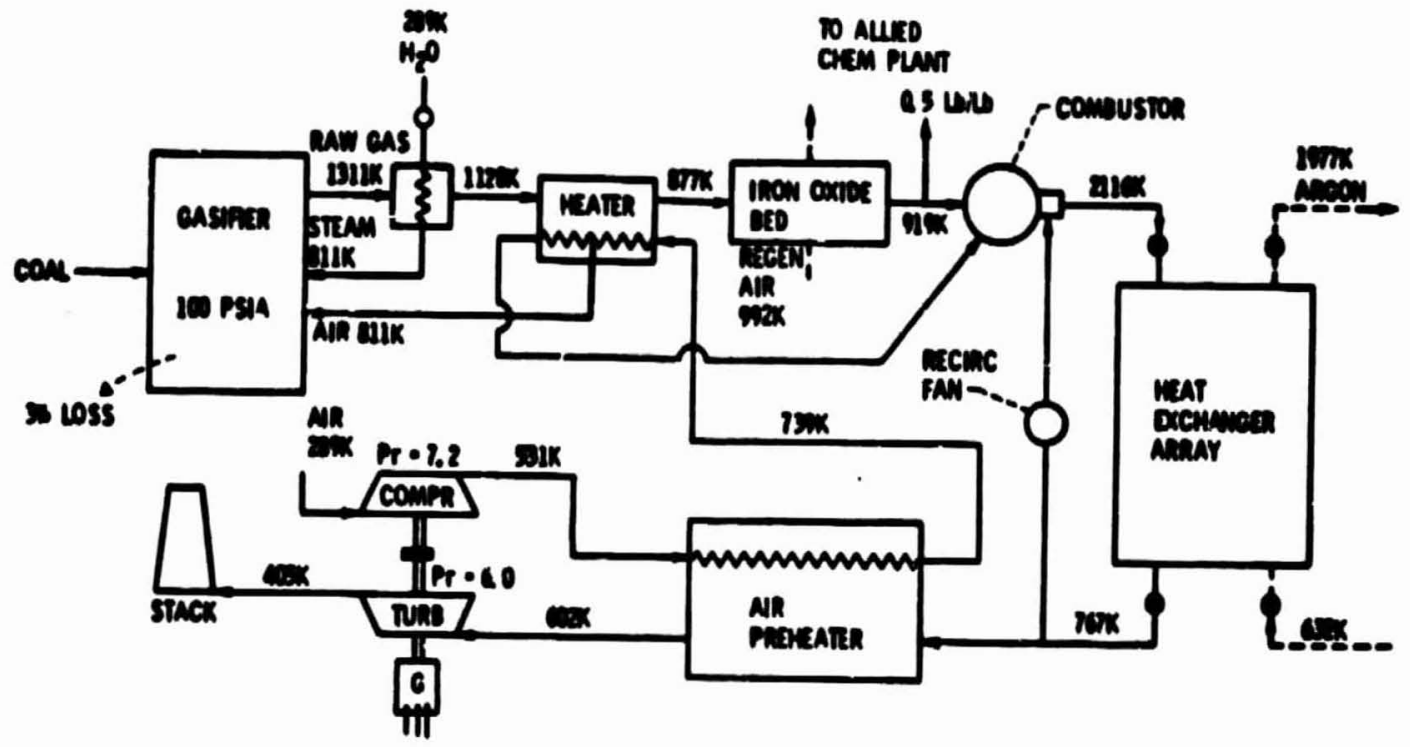

Fpure 3. - IG gasilior combustion systom.

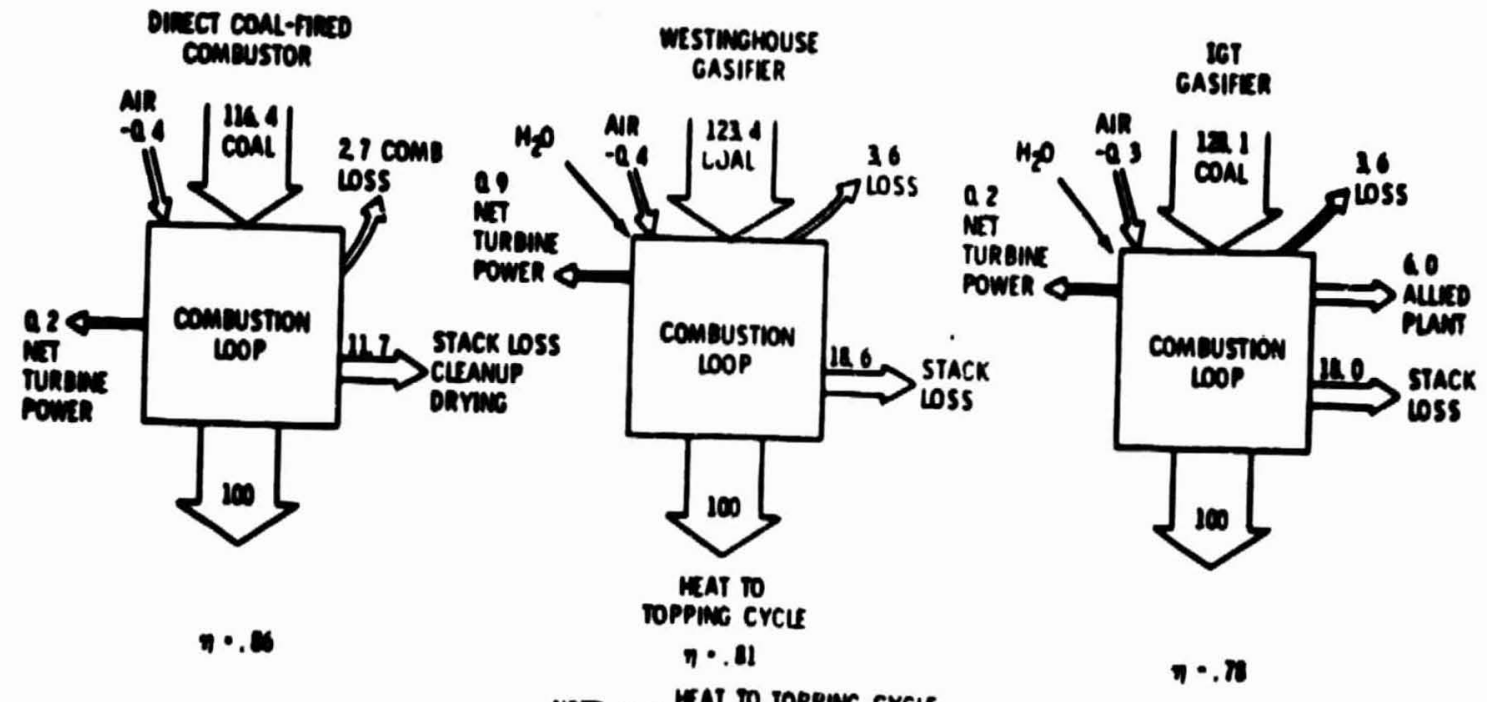

NOT: $\eta$ EEAT TO TOPPNG CYCLE

Faure 4 - Combuation loes onorgy diagrems. 


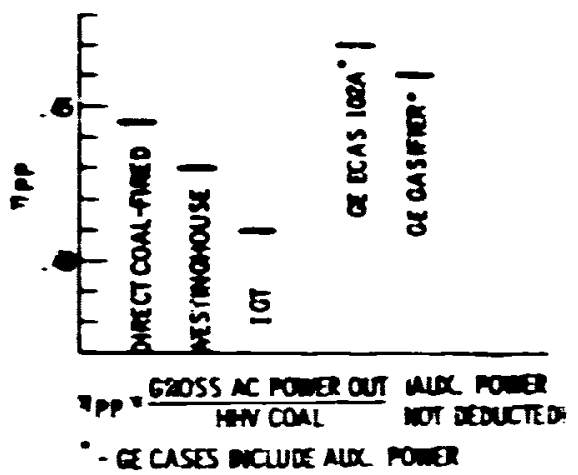

Ryre 1. - Now vent eficing 